\title{
SPORT PARTICIPATION LEGACY AND THE OLYMPIC GAMES: THE CASE OF SYDNEY 2000, LONDON 2012, AND RIO 2016
}

\author{
ARIANNE CARVALHEDO REIS,*† STEPHEN FRAWLEY, DANYA HODGETTS,§ \\ ALANA THOMSON,ף AND KATE HUGHES\# \\ *School of Science and Health, Western Sydney University, Campbelltown, NSW, Australia \\ †School of Business and Tourism, Southern Cross University, Coffs Harbour, Australia \\ $\ddagger$ Australian Centre for Olympic Studies, University of Technology Sydney, Lindfield, NSW, Australia \\ §Physical Activity Research Group, School of Human Health and Social Services, \\ Central Queensland University, North Rockhampton, QLD, Australia \\ qDepartment of Tourism, Sport and Hotel Management, Griffith University, QLD, Australia \\ \#Carnegie Faculty of Sport and Education, Leeds Metropolitan University, Leeds, UK
}

\begin{abstract}
Sport participation as a legacy of the Olympic Games (OG) has frequently featured as a component of the "legacy package" that government bodies and organizing committees promote to the local communities to gain support for the hosting of these mega-events. However, only recently increased sport participation has been explicitly included as part of a legacy plan in OG candidature files. This article examines the changes and development of sport legacy planning and implementation from Sydney 2000, London 2012, and Rio 2016. The three case studies confirm that sport participation legacies are only achieved if host governments engage the community, develop long-term strategies, and coordinate efforts between different government portfolios and with a range of relevant stakeholders. So far, there is limited evidence available to demonstrate that relevant government bodies have attempted to strategically leverage the Games with the purpose of developing a sport participation legacy for the wider population.
\end{abstract}

Key words: Sport participation; Mega-events; Legacy; Physical activity

Introduction

Pierre de Coubertin had three main objectives when establishing the modern Olympic Games: to foster the goals of competitive sport; to provide facilities to promote further sporting development; and to improve the profile of sports through better opportunities for practice and competition (Chalkley \& Essex, 1999). The Sydney, Athens, and Beijing Olympic Games addressed this third objective through general statements about inspiring citizens to participate in sport (Jinxia \& Mangan, 2008;

Address correspondence to Arianne Carvalhedo Reis, Ph.D., School of Science and Health, Western Sydney University, Narellen Road, Campbelltown NSW 2560, Australia. Tel: +61 24620 3136; E-mail: a.reis@westernsydney.edu.au or Stephen Frawley, Ph.D., Australian Centre for Olympic Studies, University of Technology Sydney, 100 Eton Road, Lindfield NSW 2070, Australia.

E-mail: Stephen.Frawley@uts.edu.au 
Pappous, 2013; Sydney Olympic Games Review Committee, 1990). More recently, the London and Rio Olympic Games have explicitly included increased sport participation as an envisioned legacy of the Games in their bid books (British Olympic Association, 2004; Rio 2016, 2009). This article examines the changes and development of sport legacy planning and implementation from Sydney 2000, London 2012, and Rio 2016. The purpose is to assess how sport participation has been encouraged/promoted, strategically or not, by the hosting of the Olympics. By including the only two Summer Olympic Games to specifically include sport participation as an intended event legacy (i.e., London 2012 and Rio 2016), and one that generally suggested that the event would inspire sport participation in the host country (i.e., Sydney 2000), this article compares different approaches to leveraging the Olympic Games for sport participation and their (potential) outcomes, with the aim of providing a better understanding of legacy efforts and associated discourses.

\section{Sport Participation Legacies}

Research conducted on sport legacy and megaevents has been largely focused around increasing participation (Brown \& Massey, 2001; Coalter, 2007b; Frawley \& Adair, 2013; Hindson, Gidlow, \& Peebles, 1994; Reis, Sousa-Mast, \& Gurgel, 2013; Toohey, 2010; Veal, Toohey, \& Frawley, 2012); improving facilities (Cashman \& Darcy, 2008; Darcy, 2003; Kidd, 2013; McCloy, 2003; Parent, 2008a; Shipway, 2007; Weed, Coren, \& Fiore, 2009); strengthening sport organizations (Cashman, 2006; Coalter \& Taylor, 2008; Parent, 2008b; Shipway, 2007); and improving sport policy (Kidd, 2013; Parent, 2008b). These types of anticipated sport benefits are regularly presented by host governments and organizing committees in order to encourage community support for staging these events (Frawley \& Adair, 2013; Hindson et al., 1994; Toohey, 2010; Veal et al., 2012). This in turn can create an unrealistic expectation, as Toohey (2010) explained using the case of Sydney 2000: "the federal government's investment in the Games . . . [meant] there were also expectations that recreational sport would be a beneficiary of the legacy that the Games would provide. One prospect was that the nation's recreational sport participation would increase" (p. 2772).

There are often expectations by sports officials and the general public that the staging of megaevents will generate sport-related benefits even in situations where there has been no explicit sport development objective or strategy (Toohey, 2010). These expectations have been described as the "trickle-down effect" (Potwarka \& Leatherdale, 2016), and increasing sport and physical activity participation through the trickle-down effect is the most frequently identified sport development legacy in the research literature (Hindson et al., 1994; Veal et al., 2012). This effect is said to take place when government investment in staging sport events combined with the successes of elite athletes and the associated media coverage leads to "increasing numbers of people taking up these sports, increased membership of clubs in the respective sports and high performance aspirations on the part of the club members, coaches and administrators" (Hindson et al., 1994, p. 17). Mega-events like the Olympic Games have been considered central to this notion (Baade \& Dye, 1990; Brown \& Massey, 2001; Faber Maunsell, 2004; Gratton, Shibli, \& Coleman, 2005; Potwarka, 2015; Potwarka \& Leatherdale, 2016; Sotiriadou, Shilbury, \& Quick, 2008). Significantly, the trickle-down effect has been the basis also for sport development and physical activity policy more generally in many developed countries such as Australia and the UK since the 1970s (Coalter, 2004; Gratton et al., 2005; Hindson et al., 1994; Hogan \& Norton, 2000; Veal et al., 2012).

Notwithstanding its prevalence in policy and political discourse, a large amount of the literature supporting the trickle-down effect is based on anecdotal evidence with very few studies examining population-level data (Brown \& Massey, 2001; Murphy \& Bauman, 2007; Weed et al., 2009). The quantitative studies that have been completed have provided little evidence of sustained sport participation increases as a result of the trickle-down effect (Hanstad \& Skille, 2010; Hodgetts \& Duncan, 2015; Murphy \& Bauman, 2007; Veal \& Frawley, 2009; Weed et al., 2015; Wicker \& Sotiriadou, 2013), with only a few examples of a positive association (Potwarka, 2015; Potwarka \& Leatherdale, 2016).

When trickle-down effects are discussed generally in terms of increasing participation in sport and 
physical activity, underlying mechanisms such as a demonstration effect and role-modeling effect are offered by way of explanation (Hogan \& Norton, 2000; Kidd, 2013; Weed et al., 2009). The demonstration effect refers to the exposure of a sport or athlete to widespread media coverage and the potential impact on future participation (Green, 2007; Stewart, Nicholson, Smith, \& Westerbeek, 2004). In a similar way, the role-model effect refers to successful athletes inspiring young people to play sport more often and therefore also increasing overall physical activity (Weed et al., 2009). However, critics argue that demonstration and role-modeling effects are not always positive and, in fact, negative consequences can also emerge (EdComs, 2007); for more than 40 years it has been suggested that some people may actually be discouraged from taking up a particular sport due to a perceived gap in competence (Bloomfield, 1973). Recent studies have used behavior change models from the physical activity literature such as the self-efficacy theory (Boardley, 2013), the theory of planned behavior (Potwarka, 2015), and the transtheoretical model (Weed et al., 2015) to add rigor to the analysis of the trickle-down effect through identification of how it might work and on whom they would be most effective. However, this stream of research is still in development and more knowledge in this field is required to reach more definite conclusions of the real impacts of the trickle-down effect and therefore of its role in establishing a sport participation legacy from the Olympic Games.

\section{Talking Legacy}

Although the concept of event legacies emerged in the academic literature in the early 1990s (Getz, 1991), the use of the term is still contested and regarded as elusive by some mega-event researchers (Cashman, 2006; Gratton \& Preuss, 2008; Matheson, 2010; Preuss, 2007; Thomson, Schlenker, \& Schulenkorf, 2013). More specifically, the concept of sport legacy is also often viewed as an ambiguous term (Coalter, 2007a; London East Research Institute, 2007). Coalter (2007b), for instance, argues that there is little conceptual clarity on whether sport legacy refers to "physical activity, recreational sport, competitive sport or elite sport” (p. 109). The ambiguous treatment of sport legacy is problematic because unclear notions enable governments to claim the achievement of overall legacies based on developments in one area (e.g., construction of facilities and infrastructure, or sport volunteers) while hiding failures in other areas (e.g., sport participation) (Weed et al., 2009).

In addition, MacAloon (2008) suggests that the concept of legacy has remained elusive due to the political interests of the International Olympic Committee (IOC). He argues that the IOC has promoted "legacy talk," that is, a discourse that seeks to promote the legacy concept (MacAloon, 2008, p. 2065). Legacy talk is seen to have developed to curb criticism of the Olympic movement and to sustain global support (Veal et al., 2012). MacAloon (2008) argues that this discourse enables governments and event organizers to treat legacy as a vague and simplistic concept, pitched as a desirable outcome for host cities, but attracting very little critique. Such arguments resonate with the work of Roche (1994), who highlighted that conventional, democratic, and rational decision-making processes are often ignored in major event projects, leading to the decisions being made by political leadership and urban elite groups. MacAloon (2008) argues that it is therefore improbable that meaningful engagement with notions of legacy by event governing bodies and host governments is likely to occur.

Given the variety of uses of the term "sport participation legacy" in official documents, and in order to account for the different aspects covered by strategies and policies based on such a term, for the purposes of this article sport participation legacy will be used to denote participation in both organized sport and physical activity more generally.

\section{Forward Planning/Event Leveraging}

Chalip (2004) offers an alternate perspective to MacAloon's (2008), suggesting that event impacts and legacies are only as good as the strategic planning implemented to support them. Chalip (2004) argues that "it is no longer suitable merely to host an event in the hope that desired outcomes will be achieved; it is necessary to form and implement strategies and tactics that capitalise fully on the opportunities each event affords” (p. 245). As 
such, stakeholders should be attempting to ensure events are strategically planned to get a return on investment (Ritchie, 2000). Instead of hoping for a trickle-down effect to occur, there is an increasing call in the literature for sport mega-events to be integrated into broader sport development planning (Coalter, 2004; Frawley \& Cush, 2011; Hanstad \& Skille, 2010; Sousa-Mast, Reis, \& Gurgel, 2013; Veal et al., 2012). For example, Coalter (2004) has highlighted the importance of integration and investment in sport systems arguing that the lack of participation increases stem from the supplyside failures of associated sport organizations. He argues that sport organizations need to be prepared to benefit from the raised profile their sports gain from the hosting of sport mega-events. Furthermore, to encourage increased demand in participation, investments and developments are required in facilities and venues, volunteer training, community engagement, and junior development programs (Frawley \& Cush, 2011; Hanstad \& Skille, 2010).

Event leverage is defined as a process of identifying a sport event as an opportunity, and then planning and implementing a series of strategies to ensure the desired outcomes can be achieved (Chalip, 2006; Morse, 2001; O’Brien, 2006; O’Brien \& Chalip, 2007). Studies of event leverage also differ somewhat from studies of event legacy and impacts (O’Brien \& Chalip, 2007). Event legacy and impact studies typically take an ex post focus where researchers measure impacts at the end of an event. In contrast, event leverage studies take an ex ante focus and look at the strategies put in place at the beginning of the event planning cycle. O'Brien and Chalip (2007) argue that while the ex post focus of impact and legacy studies has been useful for understanding the extent of event impacts, they have provided limited insights into "why or how particular impacts occur or are absent” (p. 322). The authors explain that an event leverage perspective demands a "more strategic approach that looks forward to planning how host communities can derive sustainable benefits from sport events" (O’Brien \& Chalip, 2007, p. 319).

Event leverage models are useful in that they set out a schematic process to guide the efforts of event stakeholders to maximize benefits of large-scale sport events. O'Brien and Chalip (2007) acknowledge that the event leverage models are simplistic representations of processes, and that there are more complex influences that warrant further understanding, particularly in the case of leveraging for social outcomes. They highlight that the development and implementation of social leverage strategies has been stunted for reasons including: the political expediency of economic development, which means governments give preference to economic leverage strategies; the limited financial returns of causes promoting social and public good, which therefore fail to encourage stakeholder action; and government fears that social leverage processes may highlight the deficiencies of their operations and policies.

These reasons are underpinned by Chalip's (2004) arguments that economic leverage activities have come to be institutionalized in the hosting of megaevents. For instance, relevant government departments and industry bodies now typically have established agencies tied into intergovernment and public-private networks that are ready to be mobilized as the opportunity arises to capitalize on the economic opportunities afforded by events (Stokes, 2006). In contrast, social leverage, including leverage for sport participation legacies, have not experienced such institutionalization and remain largely underdeveloped.

\section{And How Do We Know if There Is a Legacy?}

The evaluation of legacy has also come under scrutiny, mainly because it rarely occurs (Cashman, 2006). Evaluations require the establishment of baseline data and access to consistent and comparable data to demonstrate event legacies, and these are often difficult to come by (Dickson, Benson, \& Blackman, 2011). Additionally, a long-term perspective is needed to determine if legacies have been sustained after an event (Matheson, 2010). Gratton and Preuss (2008) suggest that a timeframe of 15 to 20 years is needed to determine the true worth of legacies. Such a long timeframe also brings with it issues of attribution or determining causality (Preuss, 2007). Where evaluations of legacy have occurred, they are often celebratory and lacking in critique (Cashman, 2006). The literature has criticized such evaluations for focusing only on planned, positive, tangible legacies of events (Matheson, 2010) and failing to "sufficiently 
compare outcomes with the stated objectives made to the host city at the time of the bid" (Cashman, 2006, p. 18).

Recently there have been efforts to address these criticisms of legacy evaluation. For example, in the early 2000s, the IOC formalized commitments to sport development legacies by implementing an evaluation framework-the Olympic Games Impact (OGI) project. Olympic bid cities are now obliged to respond to sport development-related questions in the IOC's Candidature Procedure and Questionnaire, and host cities are obliged to capture data across a number of indicators beginning 2 years before the election of the host city and continuing until 2 years after the event (IOC, 2004). The indicators cover a range of economic, social, and environmental factors.

Although the inclusion of sport developmentrelated legacy questions in the IOC questionnaire is a step forward, Veal et al. (2012) argue that some of the questions are problematic. For example, sport development is not defined in the questionnaire, which means that rather than focusing on sportfor-all (i.e., mass participation) legacies, bid city responses may focus solely on elite sport development and still meet the IOC's criteria. Veal et al.'s (2012) appraisal resonates with MacAloon's (2008) critique of the IOC's notion of legacy more generally, with doubts about how meaningful the IOC's engagement with legacy is and the depth of its commitment to securing legacies for host cities. Veal et al. (2012) acknowledge that while the IOC's legacy developments are not perfect, they do demonstrate an evolution from "rhetorical commitment [s] . . [to a] formal requirement imposed on bidding cities to commit and plan for a sport participation legacy” (p. 176).

Chalip (2004) and Matheson (2010) argue that the increased interrogation and scrutiny of legacies from mega-events offer an opportunity for greater understanding of the complexities and challenges of securing legacies. Chalip (2004) argues that the justification of events through promises of specific outcomes means governments have a moral obligation to deliver the best outcomes possible. Where outcomes are not delivered, then "taxpayers may eventually demand an end to the public subsidies on which events commonly rely" (Chalip, 2004, p. 228). Further, Matheson (2010) points out that governments are under increased pressure to "demonstrat[e] that public expenditure [on events] reaps a suitably positive return on investment" (p. 20).

As the London 2012 Games settles into the distance, we are well positioned to take stock of the longer-term "trickle-down” outcomes from Sydney 2000, the short-term impacts from London 2012, and use insights from these events to take an informed investigation of planning for the sport participation legacies in Rio de Janeiro as the city prepares for 2016.

\section{Methodology}

This article is based on a collaborative effort to compare and contrast findings from various research projects focusing on sport participation legacies of three editions of the Olympic Games. The rationale behind it, one that guides comparative methodologies (Denters \& Mossberger, 2006), was to provide valid and reliable information about what has been achieved in this area to date to, in turn, help inform policy makers about best practices and ways forward. It is argued that comparative studies using different countries/locations as their cases have the advantage of providing an escape from ethnocentrism (Dogan \& Pelassy, 1990) and of being able to identify general trends across locations (Denters \& Rose, 2005). Most importantly, comparative research can facilitate the development of theoretical ideas and allow learning from the experiences of others (Denters \& Mossberger, 2006).

In this section, we provide the details of this process. We start by looking at the three selected cases individually, and follow up by describing how they were comparatively analyzed.

A member of the research team has been involved in the study of sport participation legacies of the Sydney 2000 Olympic Games since 1998, conducting a number of connected projects, using a variety of data, including more than 50 in-depth interviews with senior managers at national and state federations for Olympic sports in Australia where they were asked about the impact Sydney 2000 had on participation for their sports. It also involved participant observations, survey data collected by government agencies, and analysis of internal and official documents, such as the Official Report for 
the Sydney 2000 Olympic and Paralympic Games (Sydney Organising Committee for the Olympic Games, 2002) and the Sydney 2000 Bid Document (Sydney Olympics 2000 Bid Limited, 1993). The focus of this research program has been centered on understanding the changes in Australian sport participation across both children and adult populations as a result of the hosting of Sydney 2000 and other international events staged after these Games.

Similarly, one member of the research team has been investigating the 2012 London Olympic Games' promise of increased sport participation. The primary study consisted of 35 in-depth interviews with senior management and frontline delivery staff from five national governing bodies (NGBs). Three of the NGBs were Olympic sports, and the remaining two were sports with a large participation base. Ten interviews were conducted also with staff from organizations such as Sport England and Regional Development agencies that had responsibility for delivering the mass sport participation legacy. The structure of the questions was based on the five conceptual elements used by Girginov and Hills (2008): NGB involvement in legacy discourse; the influence of London 2012 on NGB strategy; how NGB Whole Sport Plans relate to the London 2012 legacy plans; what sporting and human capital NGBs have invested; and how do the NGBS considered London 2012 would help realize strategy post-Games. Due to the inability to secure interviews with key government and LOCOG staff, a content analysis of policy documents and archival records published by various governmental and nongovernmental agencies, including postevent session reports from the House of Commons and House of Lords, was conducted.

The study of sport and physical activity participation legacies of Rio 2016 has been a main focus of investigation of another member of the research team since 2011. A series of interrelated projects have been conducted in the past 5 years, using different data collection tools, including surveys, focus groups, interviews, and analysis of official documents released in Portuguese or English by the different levels of government in Brazil and Rio de Janeiro, as well as by the Brazilian Olympic Committee, the Rio 2016 Organizing Committee, and other agencies involved directly with the planning or hosting of the Games. The focus of the research program has been primarily on the sport legacies for low-income members of different communities in Rio de Janeiro, with specific projects on women and youth, but also with projects on professionals who work on the delivery of sport and physical activity programs in the city. Interview and focus group questions were principally focused on individual and collective perception of changes in the provision of sport and physical activity opportunities for the local population, and well as potential and realized legacies. Surveys included also questions about personal levels of physical activity, quality of public spaces, and availability of local programs for sport and physical activity participation.

As the lead authors became aware of each other's published work, the similarities between their methodological approaches became evident. For instance, all members of the research team used a combination of qualitative (e.g., interview, focus group, observations) and quantitative (i.e., surveys) data to analyze the sport participation legacies of the Olympic Games in focus. Interview and focus group data were all recorded and transcribed textually and then analyzed with the assistance of the software package NVivo using interpretative techniques, where a process of data coding and categorization into themes and subthemes was undertaken. ${ }^{1}$

Ongoing discussions about the material took place over several months, with an iterative process guiding the exchange of ideas and information. The team decided to use a comparative methodology using the individual case studies as the basis. The first stage of analysis used Chalip's (2004) event leverage framework to individually construct cases around three temporal categories: Event Bid and Planning for Sport Participation Legacy, Postbid, and Post-Games Outcomes. Given that the analysis of Rio 2016 was done before the event took place, the focus for this event was on the first two categories only.

Stage 2 involved a cross-analysis of cases by the research team, who identified the main themes that emerged through the different narratives. Despite the varied context between the different Olympics Games being studied, the findings were found to be strikingly similar, and clear overlapping themes 
emerged, two of which were chosen to be discussed in this article given the limitations of space to appropriately deal with all of them.

The final stage consisted of a theoretical analysis of the results, identifying the key concepts that would allow the unpacking of the main findings.

The next section will present the results from each case study, followed by a general discussion of the two selected emergent themes.

\section{Sydney 2000 Olympic Games}

\section{Event Bid and Planning for Sport Participation Legacy}

The two core priorities expressed in the bid plan for the Sydney 2000 Olympic Games were to stage a "green" Olympic Games and to organize an event that was clearly focused on the athletes (Sydney Olympics 2000 Bid Limited, 1993). Although the environment and the athletes were central to the bid plan, there was no specific reference to the creation of a sport participation legacy as a potential or desired outcome from hosting the Olympics in Sydney. The importance placed on the athletes in the bid plan was aimed at providing the best conditions and facilities for them to perform at the highest possible level (Frawley \& Toohey, 2009). Therefore, the focus was not on generating increased community or grassroots sport participation, but rather at the elite end of the sporting spectrum (Toohey, 2010).

At the national level, when the bid was won on September 23, 1993, sport policy became increasingly focused on elite performance and less concerned with community participation. Government funding for Olympic sports and elite performance was increased significantly while funding for community level sport stagnated (Stewart et al., 2004). In 1996, for instance, the Australian Government instituted Active Australia, a framework focused on lifelong participation in sport (Cashman, 2006); however, only $10 \%$ of the Australian Government's sport budget was spent on this program, with the majority of the sport budget spent on elite sport development (Stewart et al., 2004). At the state level, the New South Wales (NSW) government (i.e., the host government and major underwriter of the Games) did very little in prioritizing or leveraging the Games from a sport participation perspective outside of developing a range of permanent sport venues (Cashman, 2006).

\section{Postbid}

In the lead up to the Sydney 2000 Olympic Games three reports were published that highlighted to varying degrees that increasing sport participation was not a key concern or focus for main Olympic stakeholders such as the NSW Government, the organizing committee, or national sport federations (Veal et al., 2012). For instance, a report by accountancy and management consultancy KPMG Peat Marwick (1993) outlined the economic benefits associated with the creation of new sport facilities and infrastructure without examining the social and health outcomes potentially associated with increasing sport participation and physical activity from the use of these facilities. Another report, this time by international management consultants Keys Young (1995), concentrated on the value of organizing the Olympics and the benefits of conducting a full social impact assessment. This report examined the benefits of building new sport venues and facilities, developing and improving sport management, sport administration, sport science, sport medicine, and sport coaching capacity, but only briefly debated the possibility of generating increased grassroots sport participation (Keys Young, 1995). Unfortunately, the suggested social impact study was never conducted. The third report, published in 1990, was compiled by a standing committee within the NSW Parliament.

The report to the NSW Premier (Sydney Olympic Games Review Committee, 1990) briefly mentions the desire to see an increase in community sport participation as an outcome of staging the Sydney 2000 Olympic Games, but without any specific detail on how it could have been achieved. The report stated:

An Olympic Games that is successfully staged and financially managed leaves a positive legacy for the host city in terms of new and upgraded sporting facilities and venues; new and improved infrastructure; enhanced international recognition; increased tourism; new trade, investment and marketing opportunities, and increased participation in sport. (Sydney Olympic Games Review Committee, 1990, p. 3) 


\section{Post-Games Outcomes}

A number of studies have been completed since Sydney 2000 exploring the sport participation trends and legacy to emerge from the event. The studies are divided into two general categories: studies that explored the short-term impacts and those that explored the medium-term impacts. The studies that examined the short-term impacts are explored first, starting with the work of the Australian Sport Commission (ASC).

The ASC (2001) explored participation data collected by the Australian Bureau of Statistics (ABS) between 1998 and 2000 and found that sport participation levels fell over the examined period. The ASC (2001) concluded there was no evidence of a trickle-down effect as a result of the staging of the Sydney 2000 Olympic Games. Another study conducted by ABS researchers, Van den Heuvael and Conolly (2001), based on ABS quarterly data, found that a long-term decline in sport participation was evident between 1998 and the middle of 2000. However, the authors stated also that this decline started to reverse between August and November 2000, suggesting the possibility of a minor demonstration effect. This finding has been contradicted recently by Bauman, Bellew, and Craig (2015). They found that there was no increase in adult physical activity in the immediate period after the Sydney 2000 Olympic Games.

Research that explored the medium-term impacts of the Sydney 2000 Olympic Games offer mixed conclusions into the relationship between the staging of sport mega-events and the sport legacy for host communities. For instance, Veal et al. (2012), drawing on data collected over a decade by the ASC and the ABS, showed that there may have been a beneficial impact on overall sport participation for people aged 15 and above; however, this was achieved in non-Olympic sports. For children aged 5-14, Olympic sports witnessed a more positive impact, leading tentative support to the notion that the Olympic Games may have had a demonstration effect on younger Australians. However, the above conclusions need to be treated with caution due to the changes that took place in the survey design for the ASC adult sport participation survey and the less than ideal data collection timing for the ABS children's sport survey (for a detailed discussion of the methodological issues that were present in both surveys see Veal et al., 2012).

In addition, national registration data for Olympic sports showed little growth between 1996 and 2004. As outlined by a senior executive from the sport of athletics, the "hosting the Sydney Olympics did not have a big impact on registration numbers for the sport"; moreover, at the junior level "there was no longer-term impact.” For Australia's most successful sport at Sydney 2000, the impact on registration numbers was actually negative: a senior executive from Swimming Australia when interviewed stated that "there was no impact on registrations ... there was actually a small decrease of 5\%." This view was confirmed by another swimming official who stated Sydney 2000 "had a negative impact . . . member registrations went down. We expected them to go the other way.”

Australia's willingness to host major events post Sydney 2000 is in contrast to the mass participation numbers described above. Since the Olympics and Paralympics in 2000, the following major events have been staged in Australia: the 2003 Rugby World Cup; the 2006 Melbourne Commonwealth Games; the 2015 Cricket World Cup; the 2015 Asian Football Cup; and the 2015 Netball World Cup. In addition, in 2018 the Gold Coast will host the Commonwealth Games. These events have provided justification for elite sport spending and, as politicians know full well, no matter how well these events are planned and organized the community is likely to view their success purely on the performance of the host nation (Girginov, 2013). As the material presented next also suggests, the London 2012 and Rio 2016 experiences reaffirm such an imperative.

\section{London 2012}

\section{Event Bid and Planning for Sport Participation Legacy}

The bid for the London 2012 Olympic and Paralympic Games was the first campaign to explicitly include a plan for legacy, and sport participation legacies in particular (House of Commons: Media and Sport Committee, 2006; Veal et al., 2012). The British Olympic Association (2004) committed to create a lasting legacy to transform sport 
in the UK and it was expected that an "already sports-mad nation would get fitter and healthier" (Coalter, 2004, p. 93). London 2012's successful bid was based on four main themes: 1) Delivering the experience of a lifetime for athletes; 2) Leaving a legacy for sport in Britain; 3) Benefiting the community through regeneration; and 4) Supporting the IOC and Olympic Movement (British Olympic Association, 2004, p. 17). Although the first theme was focused on elite sport, the remaining three supported the notion of broader community engagement and participation in sport. The Candidature File set out that the delivery of programs and facilities would inspire greater youth sport activity; the Olympic Park facilities would provide increased local sport participation, a fitter society, and decreased health inequalities; and the profiling of the IOC and the Olympic Movement would inspire an interest in sport (British Olympic Association, 2004). The dominant "program theory” of how the London 2012 Games would increase mass sport participation was that the success of Team GB athletes would inspire people to change their behavior (Hughes, 2012), therefore assuming a demonstration effect would occur.

In the interviews with NGB senior managers, it was evident they have not always been clear about their role in the participation agenda:

There's been the constant changing of goal postsis it sport, is it physical activity, is it health, it is sport, is it regionalization, it is nationalization, and the problem is that it has changed every 18 months of the last 10 years. (NGB Senior Manager)

\section{Postbid}

After gaining the hosting rights for the 30th Olympiad, the media attributed the victory to Britain's ability to offer a legacy that would transform London (Keogh \& Fraser, 2005) and "change the face of British Sport” (Oliver, 2005, n/p). Following criticism of being slow to publish a plan outlining the strategies for increasing community participation in sport (House of Commons: Media and Sport Committee, 2006, 2007; Veal et al., 2012), the UK Government published Before, During and After: Making the Most of the London 2012 Games (Department for Culture, Media and
Sport, 2008a). This plan set a target to encourage two million more people to become physically active (defined as $3 \times 30$ min of moderate intensity activity per week). The target was further segmented to include one million people participating in organized sport and one million participating in general physical activity (Department for Culture, Media and Sport, 2008b). A major initiative from this plan was the mass participation scheme "Places, People, Play" where £135m of Lottery funding was committed to be spent on sport facilities, protecting playing fields, volunteering programs, and extending access to Olympic sports over 4 years (Sport England, 2010). Although this amount seems to be a substantial figure, it equates to $1.5 \%$ of the $£ 9.3$ billion Olympic Games budget for infrastructure-a disproportionate investment considering the prominence of the participation legacy in the bid (Kelso, 2010).

A report commissioned by the Cameron government elected in 2010 questioned the feasibility and progress of both legacy targets (Woodhouse, 2010). Subsequently, the sport participation targets were omitted from the resulting Plans for the Legacy From the 2012 Olympic and Paralympic Games (Department for Culture, Media and Sport, 2010). Interviewees from NGBs questioned the organization, accountability, and a budget for the delivery of legacy, with concern about "lots of little empires and no joined up thinking” (NGB Development Officer) and "who's taking the overview?" (NGB Senior Manager). NGBs recognized the practical difficulties of implementing an Olympic legacy, when there were restrictions with the Inspire Mark logo use and differences between Olympic and NGB sponsors. As one NGB Senior Manager put it: "they [Olympic sponsors] have no right to any of the grassroots programmes of the sports unless they've bought them."

\section{Post-Games Outcomes}

The UK government received considerable praise for much of its delivery strategy and success of the staging of London 2012 (Norris, Rutter, \& Medland, 2013). As is typical of a country hosting an Olympic Games and looking to capitalize on home advantage (Toohey, 2010), Team GB benefited from the unprecedented investment in elite sport programs, 
resulting in a record medal haul (House of Commons: Committee of Public Accounts, 2013). This was the first (and only) of the four key bid themes that was fulfilled. Elite sport continued to benefit in preparation for Rio 2016, with an 11\% increase for the No Compromise program (UK Sport, 2012). As for mass participation, in 2013, the government announced a "£150m Olympic legacy boost for primary school sport in England” (Department for Education, 2013, n/p). Although this was promoted by the government as a positive, it was essentially a shortfall replacement for the previously successful $£ 162 \mathrm{~m}$ School Sports Program (Campbell, 2012).

In terms of metrics for the ambitious targets for sport and physical activity, the initial target of one million people participating in general physical activity was achieved by decreasing the original physical activity target from $3 \times 30$ min of physical activity per week to just one 30-min session (House of Commons: Committee of Public Accounts, 2013). Sport England (2013) makes no mention of this criteria change when reporting that 1.4 million more people were playing sport between 2005 and 2013, and this criteria is well below the recommended physical activity levels of 150 minutes per week (World Health Organization [WHO], 2010). A postGames metaevaluation report shows statistically significant increases in sport participation, both for those exercising for $30 \mathrm{~min}$ three times per week, and for those exercising for 30 min once per week (Thornton, 2013). The report claimed "more of us are participating in sport because of the Games" (Thornton, 2013, p. 8). However, causality needs to be interpreted with caution: the report cites that $15 \%$ of adults were more motivated or more interested in sport in 2012, but how much this contributed to an increase in physical activity over a 7-year period is questionable.

Weed et al. (2015) suggest that the targets were not being met because the strategies attempting to meet the goals focused on supplying infrastructure and capacity, rather than stimulating a demand. However, this may not have been the case: one interviewee recalled that Sport England had been "encouraging NGBs to think about the consumer rather than the supply side, which is the stuff that NGBs will always be strong at. What they've been less good at is knowing about the motivations behind the people playing sport” (Sport England Senior Manager).

Another issue is that the implementation of legacy strategies was hampered by complex delivery structures, leading to a lack of accountability (Bloyce \& Lovett, 2012). This should not have come as a surprise. When a House of Commons Select Committee (House of Commons: Media and Sport Committee, 2007) examined the requirements for a London 2012 participation legacy, it determined that a cross-departmental approach including local authorities, health, education, and a wider coordination of resources was required. However, the committee also noted that sport did not have the political stature to adopt such an approach (House of Commons: Media and Sport Committee, 2007). This issue was identified by interviewees in the prebid stage. Another concern among interviewees was the tension between needing to succeed on the podium at a home Olympics, while simultaneously increasing grassroots membership and the changing remit. According to a NGB Senior Manager, this was particularly challenging because, "they know that a home gold medal is gold dust in terms of raising the profile of the sport ... so finding the focus on grassroots is a real challenge particularly with the complexity of how it is delivered."

$$
\text { Rio } 2016
$$

\section{Event Bid and Planning for Sport Participation Legacy}

In contrast to London's Olympic aspiration of increasing sport and physical activity participation among the population as a means of improving health indicators across the UK (Coalter, 2004), the sport and physical activity legacy proposed by the Rio de Janeiro bid committee, and fully endorsed by the three levels of government, was based on the idea of social development through sport. In particular, there was a strong focus during Rio's candidature on a sport participation legacy for marginalized youth (Rio 2016, 2009), taking advantage of the assumed connection between youth, sport, and social development (Coalter, 2013), one which is prolifically advocated by the International Olympic Committee through several of its programs (Kidd, 2008). 
The main strategy for developing sport/physical activity participation among the (young) population found in the bid document refers to increasing funding towards already existing federal government programs in this field. The main one, the Programa Segundo Tempo (English translation: Second Half Program) was, at the time, the flagship program of the Ministry of Sports for increasing sport participation among children and youth across the country, and has the concept of development through sport as its principal foundation (Knijnik \& Tavares, 2012; Reis, Sousa-Mast, \& Vieira, 2013). In fact, the program is supported by the UN, which highlights again its social development focus.

The two other programs cited in the bid document are the Mais Educação (English translation: More Education) and the Jogos Escolares e Universitários (English translation: School and University Games). The former is an action focused on building sport infrastructure in public schools across the country with the aim of increasing participation in sport and physical activity among school-aged children and youth. The latter is a program organized by the Brazilian Olympic Committee and funded by the federal government in which students from schools and universities of all 26 estates and the federal district come together annually to compete in Olympic sports. The Games have received an award from the IOC (Rio 2016, 2009), which may explain its strategic position in the bid document.

In addition to the increases in funding to these three programs, other programs/potential actions presented during the bidding phase of Rio de Janeiro's candidature for the 2016 Olympic Games were related to elite sports; the Olympic Training Centre, an elite training facility to be built from the proposed Olympic venues, is the main one of those.

\section{Postbid}

At the time of writing, neither the Organizing Committee nor the three different levels of government (federal, state, and municipal) have presented a strategic plan to secure a sport and physical activity legacy from the Olympic Games. The Cadernos de Legado Rio 2016 (English translation: Rio 2016 Legacy Handbook) (Ministério do Esporte, 2009), presented immediately after the nomination, stands as the only reference document, and one that was not created in consultation with local stakeholders or the population in general ${ }^{2}$ - therefore not taking into account their demands. It has not been revised or revisited ever since.

The lack of legacy planning after the bid was won was further complicated in 2011 by allegations of corruption made against the Minister for Sport, who was responsible for overseeing Programa Segundo Tempo. Programa Segundo Tempo is the longest uninterrupted national sport program in Brazil's recent history, and, as noted above, one of the main programs funded to secure a youth sport/physical activity participation legacy from Rio 2016. These corruption allegations brought Programa Segundo Tempo under scrutiny, with public officials questioning the purpose, the administration, and the overall legitimacy of the program (Colon, 2011; “Epicentro da crise,” 2011). Subsequently, the large-scale investments in Programa Segundo Tempo that the Brazilian government had previously committed during the Olympic bid phase have been severely cut back (Controladoria Geral da União, 2013a, 2013b). No reports for the program have been made available to the public since 2010 and although still promoted as the Ministry of Sport's leading program for increasing sport participation in the country, the lack of reporting suggests that no monitoring or assessment is in place to ensure its effectiveness in achieving participation goals.

Aside from investments in the existing sports programs, the Brazilian government has embarked on limited changes or innovations in sport policy to secure a sport and physical activity participation legacy (Athayde, Mascarenhas, Matias, \& Miranda, 2013). Although some new programs have been established by the different levels of government, it is anticipated that the potential effect of these programs may have been cancelled out by the dissolution of other programs. An example of program dissolution at the state government level is the Projeto Rio 2016 (English translation: Rio 2016 Project). The project was established in 2009, soon after Rio's nomination as a candidate city for the Olympic Games. Projeto Rio 2016 was developed, implemented, and financed by the State Government, and was promoted as Rio's main 
sport participation legacy program, providing sport and physical activity opportunities for children and youth from low income communities. However, in September 2013 the program was suddenly halted, with participants left with no explanation as to the reasons why such a sudden finish occurred (Globo. com, 2013; Konchinski, 2013).

In the eyes of the main conduits of these public programs, that is, sport and physical activity professionals, there is little hope that any investment in sport participation programs will be sustained in the long term. As a physical education teacher who works in public sport for development programs stated:

We have hope, but if we consider it rationally, in our country, in our reality, I'd say that any of these programs will only last until the Games [in 2016] because unfortunately what reigns here is politics [. . .] As long as it is interesting for the politicians to have a focus on sport [they will maintain it]. After 2016, we don't know what's going to happen. That's the fear of all who work with sports [in Rio].

However, there is an expectation of a trickledown effect to occur, despite the lack of investment, as another sport professional stated:

I believe that these [sport] events can motivate people to practice physical activity because as people have access to these events through media channels, informal conversations, [. . .] people get exposed to this information, so I believe this can motivate people to engage in physical activity.

At the elite sport level, the Brazilian government, together with the Rio 2016 Organizing Committee (which is mostly composed of previous members of the Brazilian Olympic Committee), frequently states their aim of placing the country in the top 10 medal winners. However, strategies are not clearly established and investments seem uncoordinated. The main scheme presented was the Plano Brasil Medalhas (English translation: Brazil Medals Plan), which is to receive an investment of R\$1 billion between 2013 and 2016. Two thirds is to go to support technical commissions and athletes, and one third is to go to developing/ creating training facilities. The elaboration of the Plan did not involve public consultation/participation and no official documentation about the strategy can be accessed by the general public, apart from a PowerPoint presentation with some investment numbers, general statement of objectives, and some attractive images of Brazilian athletes (Ministério do Esporte, 2013). Discussions surrounding the Plano Brasil Medalhas are focused solely on the financial investments made for Brazil to reach the top 10 placing (Santos, DaCosta, \& Silva, 2012), without much evidence that thought has been put into the more complex factors involved in reaching the impressive results aspired, such as the implementation of development pathways and sustainable sport policies (De Bosscher, Sotiriadou, \& van Bottenburg, 2013).

\section{Comparative Analysis}

Two major themes have emerged from a comparison of the findings of the case studies presented above: 1) the elite/mass divide in sport legacy planning, and 2) the challenges related to implementation of strategies and measuring outcomes.

\section{The Elite/Mass Divide in Sport Legacy}

The elusiveness of the term legacy (MacAloon, 2008) and, in particular, of the term sport participation legacy (Coalter, 2007b), may contribute to the current and persistent divide between investment in elite sport and in grassroots participation as a means of achieving a "sport participation legacy." Given that there is no clear directive from the IOC to what type of sport legacy the Olympic Games should foster (IOC, 2004), the imperative of succeeding at the world stage seems to take prominence and investment in Olympic sports at the elite level seems to receive most of the bonus from the host nation. As pointed out by Kosović (2011), sport is "the domain of the spectacle in which society's deepest values are being celebrated (competition, winning, success, strength, money)” (p. 21), making the Olympic Games the perfect symbols for being a major actor in the spectacle.

All three Games analyzed demonstrate the predominance of such an imperative. Using Sydney 2000 as an example, the significant shortcomings in the research process that attempted to account for the sport legacy to emerge out of the event (Veal et al., 2012) highlight that sport participation 
legacy was not viewed as overly important by key stakeholders such as the Australian Government, the NSW Government, nor the local organizing committee for the Sydney 2000 Olympic and Paralympic Games. In addition, there was no detailed before-event planning that investigated the possibility of how a sport participation legacy could be achieved through hosting the Sydney Olympics. This is in direct contrast to the massive investment that has taken place in Australia over the past three decades into elite sport and sport science research. To this day, the focus on grassroots sport and community impact in Australia has been exceedingly poor (Frawley, Toohey, Taylor, \& Zakus, 2013).

After the Sydney Olympics, there was a view that sport policy would reorient towards community sport and increasing mass participation (Toohey, 2008). Yet, Australian sport policy has continued to be primarily focused on elite performance. This has resulted despite the fact that a substantial Australian Government inquiry into the sport system found that a much greater investment was required into sport at the grassroots level (Crawford, 2009). The inquiry also argued that government funding needed to shift from the elite level directly to the grassroots-conceding that the trickle-down effect that had shaped Australian sport policy for so many years had not worked. Therefore, the focus needed to shift to building from the base (Crawford, 2009). Factors that have shaped the resistance to a change in strategy include the intense lobbying by the Australian Olympic Committee (AOC). The AOC in fact drafted a detailed response to the Crawford Report in which it publicly "slammed" Crawford's recommendations, suggesting that "without elite role models, there would be less kids participating" (Owen, 2009, n/p).

For London 2012, even though a clear directive existed in the Candidature File for an increase in mass participation, the decision in 2003 to bid for the Olympic Games came less than 12 months after a government article titled Game Plan concluded that mass sport participation was not influenced by hosting or success at mega-events, and included a focus on locally delivered health and community outcomes (Department for Culture, Media and Sport \& Strategy Unit, 2002). The NGB interviews showed a recurring belief that winning and success at London 2012 was a precursor to the inspiration required for the trickle-down effect. This seems to have justified sport's priorities for focusing on elite sport. Contributing to this were changes in government policy concerning participation, and NGB concerns about opposing sponsors.

The focus on elite sport development is also clear in the sport participation legacy being promoted for Rio 2016. In official documents, proposals for mass sport participation programs frequently do not provide investment figures or clear target groups, whereas elite sport programs are presented with more detail regarding financial and infrastructural investment as well as a clear characterization of recipients (Ministério do Esporte, 2009; Rio 2016, 2009). Interview and focus groups further reinforced what the documents indicate: that there is an overall expectation that improved sporting performance by Brazilian athletes will lead to positive media exposure, that in turn will create an awareness of the different sport opportunities, which, in the end, will trickle down to inspire broad participation. In what seems to be a vicious circle, proper planning and investment in mass participation strategies to take advantage of the potential heightened awareness and interest in sport participation is simply not found anywhere in official documents.

\section{Implementing Strategies and Measuring Outcomes}

Closely related to problems of planning and implementing largely ineffective strategies for achieving elusive outcomes are the challenges presented by measuring effects, or the actual legacies. A key one identified in all three case studies relates to the availability of data, or the consistency in collecting relevant data that can help inform future policy and planning as well as evaluate strategies and actions. As previously highlighted, the OGI study is certainly a step in the right direction, but one that has not taken the full toll of addressing the issue, particularly when it comes to sport participation legacy (Homma \& Masumoto, 2013). For instance, the first report of the Rio 2016 OGI presents some superficial, and contestable, data about pre-Games sport development impacts. The authors start the relevant section of the report presenting a caveat indicating that the only substantial and official data set available for analysis on sport development in the country was last collected in 2006, 1 year prior 
to their baseline date. Results from a national survey on physical activity participation for the years 2009, 2010, and 2011 are then presented, but the sharp increase identified from 2010 to 2011 is explained by a change in the methodology used, and is dismissed by the authors. For the comparable data (i.e., between 2009 and 2010), Rio de Janeiro residents presented a slight drop in leisure time physical activity participation, while the broader Brazilian population results remained stable. Data on sport programs available for the general population is sourced from the Rio 2016 Organizing Committee itself and no full reference to the source is provided, making it difficult to verify its accuracy and validity. Official data are only provided for a scholarship program for elite athletes that was implemented in 2005 and is still in operation.

What seems clear now is that the numbers' game reflected in these three case studies will continue and undoubtedly be played in future mega-event venues. It is suggested here that, in terms of influencing the potential for future events to create a legacy of mass sport participation, more pertinent is to consider the efficacy of the mechanisms proposed to generate legacy and the contexts in which it is anticipated they will operate (Hughes, 2012). For the London 2012 Games, the contexts in which the proposed mechanisms were set, that is, national governing bodies delivering programs, volunteer delivery capacity, and facility availability, were not conducive to producing the desired outcome of increased mass sport participation. These mechanisms were found to have been hindered by the identified environmental contexts, which consisted of a dependency on elite success, a flawed understanding of the effectiveness of role models, limited geographical reach beyond London, variable applicability between individuals, and incompatible sporting relevance. In addition, a review of the governance of the London 2012 legacy suggests that localized sport development legacy strategies, rather than the adopted top-down approach, could have been more successful in achieving London's Olympic promises (Girginov, 2011). This was compounded by the impact of change in government focus and economic investment between the elite/ grassroots and a varying focus between sport and physical activity (Bell \& Gallimore, 2015; Green, 2007, 2012; Grix \& Charmichael, 2012).
The case of Rio 2016 is even more dramatic. At the outset of the Rio bid there was no strategic plan for innovations in sports policy or programming to achieve increases in sport and physical activity participation in the host city of Rio de Janeiro, or the host nation of Brazil (Reis et al., 2013). There is evidence that significant financial resources are being directed to sport programs, all under the banner of Olympic Games “legacy.” However, so far there have not been concerted efforts to effectively leverage the Games for developing a longterm sport participation legacy for the wider Rio de Janeiro and Brazilian population. Strategies that attempt to democratize access to sport and physical activity have been scattered, ad hoc, and inconsistent, when available.

Ouriques (2010) argues that "sport development, something forgotten and little explored [in Brazil] from a structural and planning point of view, becomes the ideological justification for allowing massive expenditures in the area" (p. 138, translated by the author) without proper public scrutiny. Recent studies in this field have highlighted and confirmed the issues raised above, and point to pessimistic outcomes (Mascarenhas, 2012; Reis et al., 2013; Santos et al., 2012).

Therefore, in general, what these three case studies indicate is that a loose focus on, or naïve expectations of, potential trickle down or demonstration effects together with investment on elite sports at the expense of mass participation strategies are not conducive to a sustainable and long-term increase in involvement with physical activity and sport by the local population.

\section{Discussion}

The three case studies presented here reaffirm what recent research into sport participation legacy has consistently found: that to secure sport participation legacies and resultant social outcomes there is a need for host governments to engage the community, develop long-term strategies, and coordinate efforts between different government portfolios and with a range of relevant stakeholders (Cashman, 2006).

The Sydney 2000 case highlighted the mistaken thinking that hosting an event will lead to an automatic trickle-down effect, and therefore the positive 
realization of participation outcomes. Increasing participation was not a specific objective of Sydney 2000, and almost a decade and a half of research has demonstrated that without concerted efforts to build a shared vision for a participation legacy through an integrated approach that involves all parts of the prevailing sport system, positive participation outcomes are unlikely to emerge (Veal et al., 2012). In line with this understanding, event bid committees have shifted their approach in creating bid documents. Since the successful London 2012 bid (announced in 2005), organizing committee objectives focused on increasing sports participation have been more explicitly outlined with both the London 2012 and Rio 2016 bids including participation-based event objectives.

However, significantly, the London 2012 and Rio 2016 experiences evidence the continued influence that politics has on legacy. In both cases characteristics of what MacAloon (2008) describes as "legacy talk" are clear, with organizing committees lacking a determined commitment in planning and resourcing key legacy objectives (Frawley \& Adair, 2013). Despite the IOC's recent requirement for host cities to consider sport development legacies in their candidature files, and the implementation of the OGI, the case studies of London 2012 and Rio 2016 do not provide illustrations of thorough policy implementation as promised in the bid documents. Although the inclusion of specific participation-based objectives in bid documents may be perceived as a positive development, both London 2012 and Rio 2016 highlight that such objectives need to be supported by adequate plans, resources, and policy development, and fully integrated within the existing sport systems, if we are to see positive participation outcomes.

There is often a need for what Coalter (2004) calls the supply-side development in a host nation's sport system for it to be ready to take advantage of the opportunities presented through hosting the Olympic Games. This means there is a need for adequate planning and preparation time to get the various stakeholders on board with a shared vision for legacy and to ensure that the sport organizations and other relevant bodies have the right resources (e.g., staff, finances, volunteers, facilities, and sporting programs) in place so that real progress can be delivered. In the cases of London 2012 and
Rio 2016, the tight timeframes (London), or lack of planning (Rio), present issues for achieving supply-side development. For instance, London's plans released in 2008 set ambitious goals, and it can be questioned whether the 4-year lead up to 2012 was enough to achieve the system-side capacity development required to achieve them. In addition, the shift in the details of the participation target is an indicator that the original targets were set without fully engaging in the context of the sport system and developing an understanding of what was needed from the resourcing side of things to achieve these goals. In the case of Rio 2016, at the time of writing (2016), a few weeks out from the event, we are yet to see plans articulating how the bid promises for sport participation, or development through sport, will be achieved. Based on what we have observed in the cases of Sydney 2000 and London 2012, the absence of commitment and planning presents a critical challenge for the attainment of legacy goals.

In addition, and in contrast to the cases of Sydney 2000 and London 2012, Rio 2016 highlights how a lack of legacy planning can be complicated by the governance of legacy, with examples and allegations of political corruption that have had a critical impact on the perceived value of programs and resulted in government funding for these programs being dramatically reduced. Without current investigations of population-level data, we can only make an informed assumption that such drastic cuts in funding will significantly interrupt any legacy momentum that may have been gained so far in the lead up to the 2016 Olympic Games.

\section{Limitations and Conclusions}

As with all research, there are important limitations in this study that need to be acknowledged. First and foremost, limitations of space restrained our discussion to two emergent themes only. More could have certainly been said about policy learning, governance, transparency, and strategic alliances, for instance, as well as a more thorough consideration of other influencing factors, such as the particular social, political, and economic contexts of these cases, neoliberal and market forces, as well as power-resource relations and dependencies. However, a decision had to be made in choosing 
the emergent themes to be reported and discussed within the space limits imposed by a publication such as this. There is certainly scope for future research to further explore these and other themes.

A related limitation is the inclusion of only three Olympic Games in the analysis. As stated earlier, the focus on London 2012 and Rio 2016 was a natural one, as those were the only two Games to effectively include mention of a planned sport participation legacy to arise from hosting the Games. Sydney 2000 was included as a point of differentiation, given no overt strategy for a sport participation legacy was included in its plan, but a case that had sufficient data published on the subject. Given very little research has been published in English on Athens 2004 and Beijing 2008 on this topic, and the language (and political, in the case of Beijing) barrier in accessing official data, these Games had to be omitted from the analysis. However, we do not believe this consists a weakness of the study, but an untapped opportunity for future research. Nonetheless, this study has been able to overcome the Anglo-centric focus of most Olympic legacy research published in international journals to include Rio 2016 in the discussions.

The fact that no Winter Olympic Games were included may also be identified as a limitation of this study. However, given their size and characteristics are significantly different from the Summer events, the research team felt it was appropriate to not include them. It is, again, an opportunity for future research to compare outcomes, planned or otherwise, between Summer and Winter Games.

Lastly, but arguably most importantly, there are significant limitations in terms of availability of robust, longitudinal, population-level, comparable data to perform a more accurate analysis and comparison of the three cases. In particular, public authorities and the organizing committee for Rio 2016 have yet to provide meaningful data that can be used for analysis of impacts and legacies in the sport participation realm. Therefore, conclusions are to be taken with care, as they are based on the limited data available.

Overall, what the three case studies presented indicate is that there is limited evidence available to demonstrate that Organizing Committees and relevant government bodies have effectively attempted to strategically leverage the Games with the purpose of developing a sport participation legacy for the wider population, beyond the elite end of the spectrum, leaving this challenge for the next generation of Olympic host candidates.

\section{Notes}

${ }^{1}$ There is no room here, nor is it the purpose of this article, to discuss all these themes and subthemes, but the awareness and understanding of them by all research team members was fundamental in the initial stages of this project.

${ }^{2}$ Consultation with local stakeholders is so atypical in the Brazilian context that even the first OGI report has ignored this topic (SAGE/COPPE/UFRJ, 2014), even though it is part of the list of expected topics to be covered in this assessment (IOC, 2004).

\section{References}

Athayde, P., Mascarenhas, F., Matias, W. B., \& Miranda, N. N. (2013). O agendamento dos Jogos Rio 2016: Temas e termos para debate [The schedule of Rio 2016: Issues and terms for debate]. Pensar a Prática (Thinking the Practice), 16(3), 794-816.

Australian Sports Commission. (2001). Impact of hosting the Sydney 2000 Olympic and Paralympic Games on participation and volunteering in sport and physical activity in Australia. Unpublished paper by the Sport Development Unit, Australian Sports Commission, Canberra, Australia.

Baade, R. A., \& Dye, R. F. (1990). The impact of stadiums and professional sports on metropolitan area development. Growth \& Change, 21(2), 1-14.

Bauman, A. E., Bellew, B., \& Craig, C. L. (2015). Did the 2000 Sydney Olympics increase physical activity among adult Australians? British Journal of Sports Medicine, 49(4), 243-247.

Bell, B., \& Gallimore, K. (2015). Embracing the games? Leverage and legacy of London 2012 Olympics at the sub-regional level by means of strategic partnerships. Leisure Studies, 34(6), 720-741.

Bloomfield, J. (1973). The role, scope and development of recreation in Australia. Canberra, Australia: Department of Tourism and Recreation.

Bloyce, D., \& Lovett, E. (2012). Planning for the London 2012 Olympic and Paralympic legacy: A figurational analysis. International Journal of Sport Policy and Politics, 4(3), 361-377.

Boardley, I. D. (2013). Can viewing London 2012 influence sport participation? A view point based on relevant theory. International Journal of Sport Policy and Politics, 5(2), 245-256.

British Olympic Association. (2004). London Olympic bid: Candidature file. Retrieved from http://webarchive. nationalarchives.gov.uk/20070305103412/http:/www. london2012.com/news/publications/candidate-file.php

Brown, A., \& Massey, J. (2001). The sports development impact of the Manchester 2002 Commonwealth Games: Initial 
baseline research. Retrieved from https://www.academia. edu/481125/The_sports_development_impact_of_the_ Manchester_2002_Commonwealth_Games_initial_ baseline_research

Campbell, D. (2012). Will London's Olympic public health legacy turn to dust? British Medical Journal, 344, e4207.

Cashman, R. (2006). The bitter-sweet awakening: The legacy of the Sydney 2000 Olympic Games. Petersham, Australia: Walla Walla Press.

Cashman, R., \& Darcy, S. (2008). Benchmark games. Petersham, Australia: Walla Walla Press.

Chalip, L. (2004). Beyond impact: A general model for sport event leverage. In B. W. Ritchie \& D. Adair (Eds.), Sport tourism: Interrelationships, impacts and issues (pp. 226252). Clevedon, UK: Channel View Publications.

Chalip, L. (2006). Towards social leverage of sport events. Journal of Sport \& Tourism, 11(2), 109-127.

Chalkley, B., \& Essex, S. (1999). Urban development through hosting international events: A history of the Olympic Games. Planning Perspectives, 14, 369-394.

Coalter, F. (2004). Stuck in the blocks? A sustainable sporting legacy. In A. Vigor, M. Mean, \& C. Tims (Eds.), After the gold rush: A sustainable Olympics for London (pp. 91-108). London: IPPR and Demos.

Coalter, F. (2007a). A wider social role for sport. Oxon, UK: Routledge.

Coalter, F. (2007b). London Olympics 2012: The catalyst that inspires people to lead more active lives? The Journal of the Royal Society for the Promotion of Health, 127(3), 109-110.

Coalter, F. (2013). Game plan and the spirit level: The class ceiling and the limits of sports policy? International Journal of Sport Policy and Politics, 5(1), 3-19.

Coalter, F., \& Taylor, J. (2008). Large scale sports events: Event impact framework. Stirling, Scotland: University of Stirling.

Colon, L. (2011, February 19). Cercado por fraudes, Segundo Tempo turbina caixa e políticos do PC do B [Surrounded by frauds, Segundo Tempo turbines bank accounts of politicians from the political party PC do B]. O Estado De São Paulo. Retrieved from http://politica.estadao.com. br/noticias/geral,cercado-por-fraudes-segundo-tempoturbina-caixa-e-politicos-do-pc-do-b,681876

Controladoria Geral da União. (2013a). Portal da transparência. Gastos diretos por ação governamental [Transparency Portal. Direct spending by government action]. Retrieved from http://transparencia.gov.br/PortalCompras DiretasPesquisaAcao.asp?Ano=2016\&Ordem $=1$

Controladoria Geral da União. (2013b). Transferência de recursos por ação de governo [Transfer of resources by government action]. Retrieved from http://www.portal transparencia.gov.br/PortalTransparenciaPesquisaAcao Favorecido.asp?Exercicio=2016\&textoPesquisaAcao $=$ \&codigoAcao $=8442 \&$ codigoFuncao $=08 \&$ siglaEstado $=P R$ \&codigoMunicipio=7881

Crawford, D. (2009). The future of sport in Australia. Canberra, Australia: Commonwealth Government. Retrieved from http://apo.org.au/files/Resource/Crawford_Report.pdf
Darcy, S. (2003). The politics of disability and access: The Sydney 2000 Games experience. Disability \& Society, 18(6), 737-757.

De Bosscher, V., Sotiriadou, K. P., \& van Bottenburg, M. (2013). Scrutinizing the sport pyramid metaphor: An examination of the relationship between elite success and mass participation in Flanders. International Journal of Sport Policy and Politics, 1-21.

Department for Culture, Media and Sport. (2008a). Before, during and after: Making the most of the London 2012 Games. London: Author.

Department for Culture, Media and Sport. (2008b). Playing to win: A new era for sport. Retrieved from http://web archive.nationalarchives.gov.uk/+/http:/www.culture.gov. uk/images/publications/DCMS_PlayingtoWin_singles.pdf

Department for Culture, Media and Sport. (2010). Plans for the legacy from the 2012 Olympic and Paralympic Games. Retrieved from https://www.gov.uk/government/uploads/ system/uploads/attachment_data/file/78105/201210_ Legacy_Publication.pdf

Department for Culture, Media and Sport, Strategy Unit. (2002). Game plan: A strategy for delivering Government's sport and physical activity objectives. Retrieved from http://www.gamesmonitor.org.uk/files/game_plan_ report.pdf

Department for Education. (2013). £150m Olympic legacy boost for primary school sport in England. Retrieved from https://www.gov.uk/government/news/150m-olympiclegacy-boost-for-primary-school-sport-in-england

Denters, B., \& Mossberger, K. (2006). Building blocks for a methodology for comparative urban political research. Urban Affairs Review, 41(4), 550-571.

Denters, B., \& Rose, L. (Eds.). (2005). Comparing local governance, trends and developments. Houndmills, UK: Palgrave.

Dickson, T. J., Benson, A. M., \& Blackman, D. A. (2011). Developing a framework for evaluating Olympic and Paralympic legacies. Journal of Sport \& Tourism, 16(4), 285-302.

Dogan, M., \& Pelassy, D. (1990). How to compare nations: Strategies in comparative politics (2nd ed.). Chatham, UK: Chatham House.

EdComs. (2007). London 2012 legacy research: Final report. London: DCMS.

Epicentro da crise, “Segundo Tempo” já distribuiu R\$881 mi: Fraudes no programa ajudaram a derrubar o exministro Orlando Silva. (2011, November 2). [Epicenter of the crisis, "Segundo Tempo" has already distributed R\$881 million: Frauds in the program helped the fall of ex-Minister Orlando Silva]. Veja. Retrieved from http:// veja.abril.com.br/politica/epicentro-de-crise-segundotempo-ja-distribuiu-r-881-mi/

Faber Maunsell. (2004). Commonwealth Games benefits study. Manchester, UK: North West Development Agency.

Frawley, S., \& Adair, D. (2013). The Olympic Games: Managerial and strategic decisions. In S. Frawley \& D. Adair (Eds.), Managing the Olympics (pp. 1-14). Basingstoke, UK: Palgrave Macmillan. 
Frawley, S., \& Cush, A. (2011). Major sport events and participation legacy: The case of the 2003 Rugby World Cup. Managing Leisure, 16(1), 65-76.

Frawley, S., \& Toohey, K. (2009). The importance of prior knowledge: The Australian Olympic Committee and the Sydney 2000 Olympic Games. Sport in Society, 12(7), 947-966.

Frawley, S., Toohey, K. M., Taylor, T., \& Zakus, D. (2013). Managing sport at the Olympic Games. In S. Frawley \& D. Adair (Eds.), Managing the Olympics (pp. 84-98). Basingstoke, UK: Palgrave Macmillan.

Getz, D. (1991). Festival events and tourism. New York: VanNostrand Reinhold.

Girginov, V. (2011). Governance of the London 2012 Olympic Games legacy. International Review for the Sociology of Sport, 47(5), 543-555.

Girginov, V. (2013). Handbook of the London 2012 Olympic and Paralympic Games: Making the games. New York: Routledge.

Girginov, V., \& Hills, L. (2008). A sustainable sports legacy: Creating a link between the London Olympics and sports participation. The International Journal of the History of Sport, 25, 2091-2116.

Globo.com (2013, August 28). Projeto Rio 2016 é encerrado pelo governo do $R J$ [Rio 2016 project is terminated by Rio de Janeiro government]. Retrieved from http:// g1.globo.com/rio-de-janeiro/noticia/2013/08/projeto-rio2016-e-encerrado-pelo-governo-do-rj.html

Gratton, C., \& Preuss, H. (2008). Maximizing Olympic impacts by building up legacies. The International Journal of the History of Sport, 25(14), 1922-1938.

Gratton, C., Shibli, S., \& Coleman, R. J. (2005). Sport and economic regeneration in cities. Urban Studies, 42(5/6), 985-999.

Green, M. (2007). Olympic glory or grassroots development? Sport policy priorities in Australia, Canada and the United Kingdom, 1960-2006. International Journal of the History of Sport, 24(7), 921-953.

Green, M. (2012). Podium or participation? Analysing policy priorities under changing modes of sport governance in the United Kingdom. International Journal of Sport Policy and Politics, 1(2), 121-144.

Grix, J., \& Carmichael, F. (2012). Why do governments invest in elite sport? A polemic. The International Journal of the History of Sport, 4(1), 73-90.

Hanstad, D. V., \& Skille, E. A. (2010). Does elite sport develop mass sport? A Norwegian Case Study. Scandinavian Sports Studies Forum, 1, 51-68.

Hindson, A., Gidlow, B., \& Peebles, C. (1994). The "trickledown” effect of top-level sport: Myth or reality? A casestudy of the Olympics. Australian Journal of Leisure \& Recreation, 4(1), 16-24.

Hodgetts, D., \& Duncan, M. J. (2015). Quantitative analysis of sport development event legacy: An examination of the Australian Surf Life Saving Championships. European Sport Management Quarterly, 15(3), 364-380.

Hogan, K., \& Norton, K. (2000). The "price” of Olympic gold. Journal of Science and Medicine in Sport, 3(2), 203-218.
Homma, K., \& Masumoto, N. (2013). A theoretical approach for the Olympic legacy study focusing on sustainable sport legacy. International Journal of the History of Sport, 30(12), 1455-1471.

House of Commons: Committee of Public Accounts. (2013). The London 2012 Olympic Games and Paralympic Games: Post-Games review. London: The Stationery Office Limited.

House of Commons: Media and Sport Committee. (2006). Memorandum submitted by the Olympic Delivery Authority. Retrieved from http://www.publications.parliament. uk/pa/cm200607/cmselect/cmcumeds/69/6102402.htm

House of Commons: Media and Sport Committee. (2007). London 2012 Olympic Games and Paralympic Games: Funding and legacy. London: The Stationery Office Limited.

Hughes, K. (2012). Mega sports events and the potential to create a legacy of increased sport participation in the host country: A London 2012 Olympic promise or Olympic dream? Routledge Online Studies on the Olympic and Paralympic Games, 1(55), 42-54.

International Olympic Committee. (2004). 2012 candidature procedure and questionnaire. Retrieved from http://www. olympic.org/Documents/Reports/EN/en_report_810.pdf

Jinxia, D., \& Mangan, J. A. (2008). Beijing Olympics legacies: Certain intentions and certain and uncertain outcomes. International Journal of the History of Sport, 25(14), 2019-2040.

Kelso, P. (2010, November 15). London 2012 Olympics: "Places People Play" legacy plan unveiled. Retrieved from http://www.telegraph.co.uk/sport/olympics/london2012/8135564/London-2012-Olympics-Places-PeoplePlay-legacy-plan-unveiled.html

Keogh, F., \& Fraser, A. (2005, July 6). Why London won the Olympics. BBC News.

Keys Young. (1995). Preliminary social impact assessment of the Sydney 2000 Olympic and Paralympic Games. Sydney: Office of Olympic Coordination, Premier's Office.

Kidd, B. (2008). A new social movement: Sport for development and peace. Sport in Society, 11(4), 370-380.

Kidd, B. (2013). The global sporting legacy of the Olympic Movement. Sport in Society, 16(4), 491-502.

Knijnik, J., \& Tavares, O. (2012). Educating Copacabana: A critical analysis of the "Second Half," an Olympic education program of Rio 2016. Educational Review, 64(3), 353-368.

Konchinski, V. (2013, September 2). Governo abandona projeto para o "principal legado social” da Rio 2016 [Government abandons project for the "main social legacy" of Rio 2016]. Retrieved from http://esporte.uol.com.br/rio2016/ultimas-noticias/2013/09/02/governo-abandonaprojeto-para-o-principal-legado-social-da-rio-2016.htm

Kosović, M. (2011). Revisiting the society of the spectacle in the post-9/11 world. Contemporary Issues, 4(1), 18-29.

KPMG Peat Marwick. (1993). Sydney Olympics 2000: Economic impact study. Sydney, Australia: Sydney Olympics 2000 Bid Limited.

London East Research Institute. (2007). A lasting legacy for London? Assessing the legacy of the Olympic Games and 
Paralympic Games. London: Great London Authority. Retrieved from https://www.london.gov.uk/sites/default/ files/gla_migrate_files_destination/archives/assemblyreports-econsd-lasting-legacy-uel-research.pdf

MacAloon, J. J. (2008). "Legacy” as managerial/magical discourse in contemporary Olympic affairs. International Journal of the History of Sport, 25(14), 2060-2071.

Mascarenhas, F. (2012). Megaeventos esportivos e educação física: Alerta de tsunami [Mega sport events and physical education: Tsunami alert]. Movimento (ESEF/UFRGS), 18(1), 39-67.

Matheson, C. M. (2010). Legacy planning, regeneration and events: The Glasgow 2014 Commonwealth Games. Local Economy, 25(1), 10-23.

McCloy, C. (2003). Facilities "Sport for All” and the Toronoto 2008 Olympic Bid. In M. de Moragas, C. Kennett, \& N. Puig (Eds.). The legacy of the Olympic Games 1984-2000. Lausanne, Switzerland: International Olympic Committee.

Ministério do Esporte. (2009). Cadernos de Legado Rio 2016 reafirmam compromisso olímpico do Brasil [Rio 2016 Legacy Handbook]. Retrieved from http://www2. esporte.gov.br/snear/rio2016/

Ministério do Esporte. (2013). Plano Brasil Medalhas [Brazil Medals Plan]. Retrieved from http://www.esporte.gov. br/arquivos/snear/brasilMedalhas/planoBrasilMedalhas. pdf

Morse, J. (2001). The Sydney 2000 Olympic Games: How the Australian Tourist Commission leveraged the Games for tourism. Journal of Vacation Marketing, 7(2), 101-107.

Murphy, N. M., \& Bauman, A. E. (2007). Mass sporting and physical activity events: Are they "bread and circuses" or public health interventions to increase population levels of physical activity? Journal of Physical Activity Fitness and Health, 4(2), 193-202.

Norris, E., Rutter, J., \& Medland, J. (2013). Making the Games. What government can learn from London 2012. Retrieved from http://www.instituteforgovernment.org. uk/sites/default/files/publications/Making\%20the\%20 Games\%20final_0.pdf

O’Brien, D. (2006). Event business leveraging: The Sydney 2000 Olympic Games. Annals of Tourism Research, 33(1), 240-261.

O’Brien, D., \& Chalip, L. (2007). Sport events and strategic leveraging: Pushing towards the triple bottom line. In A. G. Woodside \& D. Martin (Eds.), Tourism management: Analysis, behaviour and strategy (pp. 318-338). Wallingford, UK: CAB International.

Oliver, M. (2005). London wins 2012 Olympics. Retrieved from https://www.theguardian.com/uk/2005/jul/06/olympics 2012.olympicgames1

Ouriques, N. (2010). Olimpíada 2016: O desenvolvimento do subdesenvolvimento [2016 Olympics: The development of sub-development]. Motrivivência, 31(32-33), 126-155.

Owen, M. (2009, December 14). Elite v grassroots sport in fund row. The Australian.

Pappous, A. S. (2013). Do the Olympic Games lead to a sustainable increase in grassroots sport participation? A secondary analysis of Athens 2004. In J. Savery \&
K. Gilbert (Eds.), Sustainability and sport (pp. 81-87). Champaign, IL: Common Ground.

Parent, M. M. (2008a). Evolution and issue patterns for major-sport-event organizing committees and their stakeholders. Journal of Sport Management, 22(2), 135-164.

Parent, M. M. (2008b). Mega sporting events and sports development. In V. Girginov (Ed.), Management of sports development (p. 147-163). Oxford, UK: Butterworth Heinemann.

Potwarka, L. R. (2015). Exploring physical activity intention as a response to the Vancouver Olympics: An application and extension of the Theory of Planned Behavior. Event Management, 19(1), 73-92.

Potwarka, L. R., \& Leatherdale, S. T. (2016). The Vancouver 2010 Olympics and leisure-time physical activity rates among youth in Canada: Any evidence of a trickle-down effect? Leisure Studies, 35(2), 241-257.

Preuss, H. (2007). The conceptualisation and measurement of mega sport event legacies. Journal of Sport \& Tourism, 12(3), 207-228.

Reis, A. C., Sousa-Mast, F. R., \& Gurgel, L. A. (2013). Rio 2016 and the sport participation legacies. Leisure Studies, 33(5), 437-453.

Reis, A. C., Sousa-Mast, F. R., \& Vieira, M. C. (2013). Public policies and sports in marginalised communities: The case of Cidade de Deus, Rio de Janeiro, Brazil. World Leisure Journal, 55(3), 229-251.

Rio 2016. (2009). Candidature file for Rio de Janeiro to host the 2006 Olympic and Paralympic Games. Rio de Janeiro: Author.

Ritchie, J. R. B. (2000). Turning 16 days into 16 years through Olympic legacies. Event Management, 6(3), 155-165.

Roche, M. (1994). Mega-events and urban policy. Annals of Tourism Research, 21(1), 1-19.

SAGE/COPPE/UFRJ (2014). Olympic Games impact (OGI) study_Rio 2016: Relatório inicial (R1) do estudo dos impactos e do legado dos Jogos Rio 2016. Retrieved from http://www.sage.coppe.ufrj.br/index.php/noticias/325relatorio-inicial-do-estudo-dos-impactos-e-legados-dosjogos-rio-2016tm

Santos, S. C., DaCosta, L. P., \& Silva, C. H. V. (2012). Rio 2016 e o plano Brasil Medalhas: Seremos uma Potência Olímpica? [Rio 2016 and the Brazilian Medal Plan: Will we become an Olympic power?]. Podium Sport, Leisure and Tourism Review, 1(1), 66-87.

Shipway, R. (2007). Sustainable legacies for the 2012 Olympic Games. The Journal of the Royal Society for the Promotion of Health, 127(3), 119-124.

Sotiriadou, K. P., Shilbury, D., \& Quick, S. (2008). The attraction, retention/transition, and nurturing process of sport development: Some Australian evidence. Journal of Sport Management, 22(3), 247-272.

Sousa-Mast, F. R., Reis, A. C., \& Gurgel, L. A. (2013). Are cariocas getting ready for the Games? Sport participation and the Rio de Janeiro 2016 Olympic Games. Managing Leisure, 18(4), 331-335.

Sport England. (2010). Places people play: London 2012 mass participation legacy plans unveiled. Retrieved from http:// 
webarchive.nationalarchives.gov.uk/20130204115242/ http://media.sportengland.org/assets/places-people-playlondon-2012-mass-participation-legacy-plans-unveiled--3

Sport England. (2013). More young people playing sport. Retrieved from http://www.sportengland.org/media-centre/ news/2013/june/13/more-young-people-playing-sport/

Stewart, B., Nicholson, M., Smith, A., \& Westerbeek, H. M. (2004). Australian sport better by design? The evolution of Australian sport policy. London: Routledge.

Stokes, R. (2006). Network-based strategy making for events |tourism. European Journal of Marketing, 40(5/6), 682-695.

Sydney Olympics 2000 Bid Limited. (1993). The bid by the City of Sydney to host the Games of the XXVII Olympiad in the year 2000. Sydney, Australia: Author.

Sydney Olympic Games Review Committee. (1990). Report to the Premier of New South Wales. Sydney, Australia: Premier's Department.

Sydney Organizing Committee for the Olympic Games. (2002). Official report of the XXVII Olympiad (Vol. 1: Preparing for the Games). Sydney, Australia: Author.

Thornton, G. (2013). Report 5: Post-Games evaluation. London: Department of Culture, Media and Sport.

Thomson, A., Schlenker, K., \& Schulenkorf, N. (2013). Conceptualizing sport event legacy. Event Management, 17(2), 111-122.

Toohey, K. (2008). The Sydney Olympics: Striving for legacies-overcoming short-term disappointments and long-term deficiencies. International Journal of the History of Sport, 25(14), 1953-1971.

Toohey, K. (2010). Post-Sydney 2000 Australia: A potential clash of aspirations between recreational and elite sport. International Journal of the History of Sport, 27(16-18), 2766-2779.

UK Sport. (2012, December 18). UK Sport reveals record investment in bid to become first nation to surpass home Games medal haul. Retrieved from http://www.uksport. gov.uk/news/2012/12/18/uk-sport-reveals-record-investment-in-bid-to-become-first-nation-to-surpass-homegames-medal-haul
Van den Heuvel, A., \& Conolly, L. (2001). The impact of the Olympics on participation in Australia: Trickle-down effect, discouragement effect or no effect? Adelaide, SA: National Centre for Culture and Recreation Statistics, Australian Bureau of Statistics.

Veal, A. J., \& Frawley, S. (2009). "Sport for All” and major sporting events: Trends in sport participation and the Sydney 2000 Olympic Games, the 2003 Rugby World Cup and the Melbourne 2006 Commonwealth Games. Retrieved from https://opus.lib.uts.edu.au/bitstream/10453/19814/1/ lstwp6.pdf

Veal, A. J., Toohey, K., \& Frawley, S. (2012). The sport participation legacy of the Sydney 2000 Olympic Games and other international sporting events hosted in Australia. Journal of Policy Research in Tourism, Leisure and Events, 4(2), 155-184.

Weed, M., Coren, E., \& Fiore, J. (2009). A systematic review of the evidence base for developing a physical activity and health legacy from the London 2012 Olympic and Paralympic Games. Retrieved from http://nhfshare.heart forum.org.uk/RMAssets/OLC_Resources/West_Midlands/ PhysicalActivity/2488_WM.pdf

Weed, M., Coren, E., Fiore, J., Wellard, I., Chatziefstathiou, D., Mansfield, L., \& Dowse, S. (2015). The Olympic Games and raising sport participation: A systematic review of evidence and an interrogation of policy for a demonstration effect. European Sport Management Quarterly, 15(2), 195-226.

Wicker, P., \& Sotiriadou, K. P. (2013). The trickle-down effect: What population groups benefit from hosting major sport events? International Journal of Event Management Research, 8(2), 25-41.

Woodhouse, J. (2010). 2012 Olympics: A sporting legacy? Retrieved from https:/www.parliament.uk/documents/ commons/lib/research/key_issues/Key-Issues-2012Olympics-a-sporting-legacy.pdf

World Health Organization. (2010). Global recommendations on physical activity for health. Geneva, Switzerland: Author. 